\title{
Human Herpes Virus-8 Infections among Subjects with Human Immunodeficiency Virus Infection and Normal Healthy Individuals in India
}

\author{
J. Sachithanandhama ${ }^{\mathrm{a}}$ R. Kannangai ${ }^{\mathrm{a}} \quad$ A.M. Abraham ${ }^{\mathrm{a}} \quad$ G.J. Fletcher ${ }^{\mathrm{a}}$ \\ O.C. Abraham ${ }^{\text {b }}$ D. Daniel ${ }^{\text {C }}$ S.A. Pulimood ${ }^{d}$ \\ Departments of a Clinical Virology, ${ }^{\mathrm{b}}$ Internal Medicine, ${ }^{\mathrm{C}}$ Transfusion Medicine and Immunohematology, and \\ ${ }^{\mathrm{d}}$ Dermatology, Christian Medical College, Vellore, India
}

\section{Key Words}

Human immunodeficiency virus · Human herpes virus-8 ·

Real-time PCR · India

\begin{abstract}
Human herpes virus-8 (HHV-8) is etiologically associated with Kaposi's sarcoma. There is insufficient information on the epidemiology of HHV-8 infection from India. Blood samples from 87 human immunodeficiency virus (HIV)-infected individuals and 84 normal healthy blood donors were tested for the HHV-8 IgG antibodies. Further, a total of 309 whole blood samples from treatment-naïve HIV-1-infected individuals and from 70 normal healthy individuals were also collected and tested for HHV-8 DNA. The seroprevalence of HHV- 8 was $4.7 \%$ in the South Indian population. There was no significant difference in the seroprevalence of HHV-8 in the HIV-infected and uninfected patients. None of the 379 samples tested were positive for HHV-8 DNA. Our study revealed a very low exposure of the South Indian patient population to HHV-8 and multicentric epidemiological studies are needed to understand the prevalence of HHV-8 in different regions of India and to confirm any gender-specific differences in seroprevalence.
\end{abstract}

Copyright $\odot 2013$ S. Karger AG, Basel
(C) 2013 S. Karger AG, Base

0300-5526/13/0564-0253\$38.00/0
Human herpes virus 8 (HHV-8), also known as Kaposi's sarcoma (KS)-associated herpes virus, is etiologically associated with KS and other lymphoproliferative diseases like primary effusion lymphomas and Castleman's disease [1]. HHV-8 has been associated with AIDSrelated epidemic KS, but has also been identified in endemic KS. Although there is no evidence to support the role of HIV in KS pathogenesis, the high rate of KS among AIDS patients appears to be due to immunosuppression as well as shared sexual risk factors between human immunodeficiency virus (HIV) and HHV-8 [2]. HHV-8 prevalence exhibits considerable variation in different geographic regions and populations and the incidence of KS appears to increase in areas with a high prevalence rate. The seroprevalence of HHV-8 varies greatly worldwide, with $1-10 \%$ of people being infected in developed countries and up to $80 \%$ in some areas of sub-Saharan and equatorial Africa.

In HIV-infected individuals, $\mathrm{HHV}-8$ viremia had been used to predict the development of KS and also to monitor the response of therapy [3]. Real-time PCR was very successful in confirming the presence of HHV-8 DNA in clinical presentations associated with the virus. Though there are epidemiological studies on the prevalence of other herpes virus infections from the Indian subconti-

\section{KARGER}

E-Mail karger@karger.com

www.karger.com/int
Dr. Susanne A. Pulimood

Department of Dermatology

Christian Medical College

Vellore, Tamil Nadu 632004 (India)

E-Mail sapulimood@cmcvellore.ac.in 
nent, there are insufficient data on the seroprevalence and molecular detection of HHV-8 DNA and hence this study.

This cross-sectional study was approved by the Institutional Review Board and was carried out from 2007 through 2010. The study population was drawn from $\mathrm{HIV}$-infected individuals who come to the Department of Clinical Virology for CD4 and or HIV-1 viral load testing. These subjects hailed from the four southern states of India (Tamil Nadu, Karnataka, Andhra Pradesh and Kerala). Blood samples were also collected from healthy individuals and from healthy blood donors who belonged to the same states to achieve matching ethnicity with the HIV-infected subjects. Samples from healthy blood donors were collected from the first 5 volunteers who qualified for donation on a given day with informed consent. HIV status was determined for individuals by a UNAIDS-approved test and all the study participants were enrolled into the study only after informed consent was obtained.

The sample size was calculated based on previous publications on seroprevalence in Asian countries [4-5]. The prevalence rate was considered to be $14 \%$ and taking $8 \%$ as the desired precision, the sample size was calculated as 73 (95\% CI) for each group by using Epi Info 6.04. After an informed written consent, $3 \mathrm{ml}$ of whole blood samples were collected from 87 treatment-naïve HIV-infected individuals and 84 normal healthy blood donors in sterile K2 EDTA BD vacutainers (Becton, Dickinson and Company, Franklin Lakes, N.J., USA). Plasma samples were separated and stored at $-70^{\circ}$ in multiple aliquots until testing. Of $87 \mathrm{HIV}$-infected individuals, in 81 the infection was acquired by heterosexual contact including those who acquired it from their spouses, while 6 were men who gave a history of sex with men (MSM).

The samples were tested for the HHV-8 IgG antibodies by a commercial ELISA (Biotrin International, Dublin, Ireland). The manufacturer's instructions were followed strictly while performing the assay and interpretation of assay findings. This enzyme immunoassay is able to detect HHV-8-specific antibodies which bind to peptide antigens (from different proteins) that are coated on the test wells. Positive and negative controls provided by the manufacturer were included in all the assay runs and the runs were validated only when the two validation criteria were met, i.e. the mean index for positive control should be equal to or greater than 1.2 and negative control should be less than an index of 0.8. Among the samples tested, those that had a mean index of $>1.2$ were taken as positive, while an index of $<0.8$ was taken as negative. All the samples that gave equivocal results (mean index between 0.8 and 1.2) in the assay were considered as negative for the purpose of analysis. The frequency of HHV-8 antibody among blood donors and HIV-infected individuals was analyzed by the $\chi^{2}$ test using the EPI6 software program.

For the detection of HHV-8 DNA, a total of 309 whole blood samples were collected from treatment-naïve HIV1-infected South Indian individuals in sterile K2 EDTA $B D$ vacutainers (Becton, Dickinson and Company). Four hundred microliters of whole blood samples were stored at $-70^{\circ}$ in multiple aliquots until testing. These HIV-1-infected individuals were categorized into 2 groups based on CD 4 counts: group 1 with CD4 counts $<100$ cells/ $\mu$ l and group 2 with CD 4 counts $>350$ cells/ $\mu$ l. Individuals with CD4 counts of 101-349 were excluded to get clear demarcation in immune status. Whole blood samples were also collected from 70 normal healthy individuals as controls for the study.

DNA was extracted from $200 \mu$ of stored whole blood samples using the QIA amp DNA blood mini-kit (Qiagen, Hilden, Germany) according to the manufacturer's instructions. The eluted DNA was stored at $-30^{\circ}$ in a freezer until testing. Sterile Milli-Q water was used as a negative control and was included after every 5 th sample in each run of extraction to check the PCR for cross-contamination.

An in-house real-time qualitative PCR based on TaqMan chemistry was established for the amplification of HHV-8 DNA. The assay used the primers and probes from the published literature [6]. The real-time qualitative PCR was standardized using $10 \mu$ of positive control HHV-8 DNA in $12.5 \mu \mathrm{l}$ of QuantiTect Multiplex PCR NoROX master mix (Hamburg, Germany) with $0.075 \mu \mathrm{l}$ (7.5 pmol) of forward and reverse HHV-8 primers and $0.05 \mu \mathrm{l}(5 \mathrm{pmol})$ of HHV-8 Taqman probe, with a final volume of $25 \mu \mathrm{lmix}$. The thermal cycling conditions used for the HHV-8 qualitative real-time PCR were as follows: $95^{\circ}$ for $15 \mathrm{~min}, 95^{\circ}$ for $45 \mathrm{~s}$, and $60^{\circ}$ for $75 \mathrm{~s}$ for 50 cycles. The DNA was amplified and detected using real-time PCR (Rotor gene RG-3000 and RG-6000; Corbett Research, Sydney, Australia). All the runs had a positive control and multiple negative controls. Subsequent to the standardization of the assay, the lower limit of detection and specificity of the assay were also investigated.

All the samples from HIV-infected and control individuals were tested by real-time EBV PCR using a previously published protocol [7]. In HHV-8- and EBV-negative samples, the DNA integrity was established with ERV-3 PCR findings [8]. 
Table 1. HHV-8 IgG profile in normal healthy blood donors and HIV-infected individuals from South India

\begin{tabular}{llllll}
\hline $\begin{array}{l}\text { Subject } \\
\text { No. }\end{array}$ & Clinical group & $\begin{array}{l}\text { Total samples } \\
(\mathrm{n}=171)\end{array}$ & Male & Female & $\begin{array}{l}\text { HHV-8 IgG } \\
\text { positivity }\end{array}$ \\
\hline 1 & HIV-positive individuals & $87^{*}$ & 56 & 31 & $3(3.4 \%)$ \\
\hline 2 & Healthy blood donors & 84 & 78 & 6 & $5(6 \%)$ \\
\hline & & & & \\
\hline
\end{tabular}

The median age of the HIV-positive individuals in the serology study group was 34 (range 20-53), while for the healthy controls it was 32 (range 19-55). The frequency of seroprevalence of HHV-8 IgG antibody in the population tested was $4.7 \%(8 / 171)$. Three (3.4\%) among the 87 HIV-infected individuals and $5(6 \%)$ among the 84 normal healthy blood donors were found to be positive for HHV-8 IgG antibody. HHV-8 seropositivity from normal healthy blood donors and from HIV-infected individuals are shown in table 1 . The difference in the seroprevalence between the healthy blood donors and the HIV-infected individuals was not significant $(\mathrm{p}>0.05)$. Among the 8 positives, 7 (87.5\%) were men and 1 (12.5\%) was an HIV-infected woman. However, the seropositivity in men (5.2\%) was not significantly higher than in women $(2.7 \%)$. Among the positive individuals, the seropositivity in men was significantly higher when compared to women $(\mathrm{p}=0.012)$. None of the $6 \mathrm{HIV}$-positive MSMs in the study population were positive for HHV-8 antibody.

The lower limit of detection (LOD) for HHV-8 using the in-house real-time PCR was 45 plasmids/reaction $(4,500$ copies $/ \mathrm{ml})$. In spiking experiments with the plasmid in whole blood the detection limit varied from 5,000 to 30,000 copies $/ \mathrm{ml}$. The HHV-8 primers and probes did not show any cross-reactivity with other DNA viruses like HSV-1, HSV-2, VZV, EBV, CMV, HHV-6 JCV, BKV and adenovirus. All the whole blood samples from $309 \mathrm{HIV}$ infected individuals and 70 controls were negative for HHV-8 DNA. ERV-3 or EBV was amplified in all HHV8 PCR-negative samples which were used to check the DNA integrity.

The study reported here showed a seroprevalence of $4.7 \%$ for HHV-8 among the South Indian population. This is very low when compared to the seroprevalence as measured by IgG antibody for other herpes viruses like HSV, CMV, VZV and EBV. Multiple seropositivity to several herpes viruses in individuals is very high in countries like India [9]. Venkitaraman et al. [9] showed that the agespecific prevalence rates of IgG antibodies to viruses like
EBV and CMV rose rapidly after birth and reached over $90 \%$ by the 4 th year of life. In comparison, age-specific prevalence rates to VZV and HSV increased gradually after birth and reached maximum percentages of 72 and $83 \%$, respectively, in the 15 - to 25 -year age group. The seroprevalence of HHV-8 varies from country to country. An HHV-8 seroprevalence study from Nigeria showed a higher prevalence of HHV-8 in HIV-infected individuals (62\%) compared to healthy HIV-negative adult volunteers (25.9\%) from the general population [10]. Adjei et al. [11] reported an overall seroprevalence of $23.7 \%$ among HIV-seronegative healthy blood donors and 65.6\% HHV8 among HIV-infected individuals from West Africa. A multicountry seroprevalence study showed an HHV-8 positivity of $2.4 \%$ among HIV-infected individuals and $4 \%$ in normal healthy individuals in samples from India [5]. In a multicentric study from the United States among HIV-negative MSM, a 24\% prevalence of HHV- 8 was seen while in another study from Europe a higher seroprevalence of 39\% among HIV-positive MSM individuals was seen [12-13]. In striking contrast to the reports from Western and African countries, the seropositivity of HHV-8 is very low in our South Indian HIV-infected population and it is almost similar to the one reported by Ablashi et al. [5]. Moreover, the HHV-8 seroprevalence among the HIV-infected individuals was similar to the level seen among normal healthy individuals.

There are several reports on the molecular detection of HHV-8 DNA among normal healthy blood donors and HIV-1-infected individuals. Several studies conducted among healthy blood donor samples using real-time PCR showed no detection of HHV-8 viremia or a very low positivity of 1\% [14-15]. Among Brazilian HIV-1-infected individuals HHV-8 viremia was seen in $74.3 \%$ of KS-positive patients and in 3.7\% of KS-negative patients [16] and a report from Europe showed $12.6 \%$ of HIV-infected individuals to have HHV-8 DNA in their peripheral blood mononuclear cells [17]. The HHV-8 viremia reported prior to HAART was very high [3]. However, there are 
several reports on nondetection of HHV-8 among HIV1-infected individuals from Japan and Uganda $[18,19]$.

All the 379 samples we used for detection of HHV-8 DNA (collected from $309 \mathrm{HIV}$-positive individuals who never received ART and 70 control subjects) were tested for other closely related gamma herpes viruses, e.g. EBV. EBV was seen in $76.3 \%$ of HIV-1-infected individuals with virus load ranging from 100 to 543,300 copies $/ \mathrm{ml}$ and in $12.8 \%$ of the control group with virus load ranging from 100 to 5,900 copies/ml (data not shown). Our study showed that though HHV-8 belongs to the same herpes group as EBV, interestingly no HHV-8 viremia is seen among HIV-1-infected individuals from South India. Though there is serological evidence of low level exposure of HHV-8 in the South Indian population, there is no reactivation and viremia unlike that seen with EBV when the individuals become immunocompromised.

Western and African countries also reported high frequencies of KS among HIV-infected individuals [20, 21]. However, the incidence of KS is very low in our region. The first case of AIDS-associated KS was reported in a 35-year-old Indian commercial sex worker in 1993 [22] and there are only very few case reports so far from India. Reports of KS as dermatologic manifestations among immunodeficiency patients from South India are also very rare $[23,24]$. In most of these cases, the individuals were natives of the northeastern part of India. During this study period, we received a whole blood sample from an
HIV-infected patient hailing from the northeastern part of India and who presented with KS and whose sample was found to be positive for HHV-8 DNA by the same PCR used in this study [pers. commun.]. This may be because of geographical variation in the prevalence of HHV8 in India. An analogous situation is reported for Penicillium marneffei infection in HIV-infected individuals from the Indian subcontinent [25].

In conclusion, our study showed very low exposure of our population to HHV-8. The reason for the low seroprevalence and nondetection of HHV-8 DNA among HIV-1-infected individuals in the South Indian population has to be investigated further. It is also important to undertake a multicentric epidemiological study to understand the prevalence of HHV-8 in different regions especially from the northeastern states of India from where several cases of KS were reported.

\section{Acknowledgement}

We gratefully acknowledge the funding received from Fluid research fund, CMC Vellore, for the serological study and the Department of Biotechnology (Government of India), for the molecular study.

The HHV-8 plasmid originated from Dr. Shou-Jiang Gao's group and was given to us through the kind courtesy of Prof. Dr. Yan Yuan and used as the PCR-positive control. Data on molecular testing presented in this study is part of the PhD thesis of $\mathrm{Mr}$. Jaiprasath Sachithanandham.

\section{References}

1 Geraminejad P, Memar O, Aronson I, Rady PL, Hengge U, Tyring SK: Kaposi's sarcoma and other manifestations of human herpesvirus 8. J Am Acad Dermatol 2002;47:641-655.

- Laurent C, Meggetto F, Brousset P: Human herpesvirus 8 infections in patients with immunodeficiencies. Hum Pathol 2008;39:983993.

-3 Borok M, Fiorillo S, Gudza I: Evaluation of plasma human herpesvirus 8 DNA as a marker of clinical outcomes during antiretroviral therapy for AIDS-related Kaposi sarcoma in Zimbabwe. Clin Infect Dis 2010;51: 342-349.

4 He F, Wang X, He B, Feng Z, Lu X, Zhang Y, Zhao S, Lin R, Hui Y, Bao Y, Zhang Z, Wen $\mathrm{H}$ : Human herpesvirus 8: seroprevalence and correlates in tumor patients from Xinjiang, China. J Med Virol 2007;79:161-166.
5 Ablashi D, Chatlynne L, Cooper H, Thomas D, Yadav M, Norhanom AW, Chandana AK, Churdboonchart V, Kulpradist SA, Patnaik M, Liegmann K, Masood R, Reitz M, Cleghorn F, Manns A, Levine PH, Rabkin C, Biggar R, Jensen F, Gill P, Jack N, Edwards J, Whitman J, Boshoff C: Seroprevalence of human herpesvirus-8 (HHV-8) in countries of Southeast Asia compared to the USA, the Caribbean and Africa. Br J Cancer 1999;81:893-897.

-6 Watzinger F, Suda M, Preuner S: Real-time quantitative PCR assays for detection and monitoring of pathogenic human viruses in immunosuppressed pediatric patients. J Clin Microbiol 2004;42:5189-5198.

7 Sachithanandham J, Ramamurthy M, Kannangai R Daniel HD, Abraham OC, Rupali P, Pulimood SA, Abraham AM, Sridharan G: Detection of opportunistic DNA viral infections by multiplex PCR among HIV infected individuals receiving care at a tertiary care hospital in South India. Indian J Med Microbiol 2009;27:210-216.
8 Yuan CC, Miley W, Waters D: A quantification of human cells using an ERV-3 real time PCR assay. J Virol Methods 2001;91:109117.

9 Venkitaraman AR, Seigneurin JM, Lenoir GM, John TJ: Infections due to the human herpesviruses in southern India: a seroepidemiological survey. Int J Epidemiol 1986;15: 561-566.

10 Ogoina D, Onyemelukwe G, Musa BO, Babadoko A: Seroprevalence and determinants of human herpes virus 8 infection in adult Nigerians with and without HIV-1 infection. Afr Health Sci 2011;11:158-162.

-11 Adjei AA, Armah HB, Gbagbo F, Boamah I, Adu-Gyamfi C, Asare I: Seroprevalence of HHV-8, CMV, and EBV among the general population in Ghana, West Africa. BMC Infect Dis $2008 ; 18 ; 8: 111$.
Sachithanandham/Kannangai/Abraham/ Fletcher/Abraham/Daniel/Pulimood 
12 Casper C, Carrell D, Miller KG, Judson FD, Meier AS, Pauk JS, Morrow RA, Corey L, Wald A, Celum C: HIV serodiscordant sex partners and the prevalence of human herpesvirus 8 infection among HIV negative men who have sex with men: baseline data from the EXPLORE Study. Sex Transm Infect 2006; 82:229-235.

13 Martró E, Esteve A, Schulz TF, Sheldon J, Gambús G, Muñoz R, Whitby D, Casabona J, Euro-Shaks study group: Risk factors for human herpesvirus 8 infection and AIDS-associated Kaposi's sarcoma among men who have sex with men in a European multicentre study. Int J Cancer 2007;120:1129-1135.

14 Compston LI, Sarkobie F, Li C, Candotti D, Opare-Sem O, Allain JP: Multiplex real-time PCR for the detection and quantification of latent and persistent viral genomes in cellular or plasma blood fractions. J Virol Methods 2008;151:47-54.

15 Levi JE, Nascimento MC, Sumita LM: Nondetection of human herpesvirus 8 (HHV-8) DNA in HHV-8-seropositive blood donors from three Brazilian regions. PLoS One 2011; 6:e23546.
16 Keller R, Zago A, Viana MC, Bourboulia D, Desgranges C, Casseb J, Moura WV, Dietze R, Collandre H: HHV-8 infection in patients with AIDS-related Kaposi's sarcoma in Brazil. Braz J Med Biol Res 2001;34:879-86.

17 Lorenzen T, Albrecht D, Paech V, Meyer T, Hoffmann C, Stoehr A, Degen O, Stellbrink HJ, Meigel WN, Arndt R, Plettenberg A: HHV-8 DNA in blood and the development of HIV-associated Kaposi's sarcoma in the era of HAART - a prospective evaluation. Eur J Med Res 2002;28:283-286.

18 Shimizu S, Katano H, Sata T, Chen KR, Tagami $\mathrm{H}$, Hanabusa $\mathrm{H}$, Shimizu $\mathrm{H}$ : Absence of anti-human herpesvirus 8 antibody in 32 Japanese hemophiliacs with advanced HIV infection. Arch Dermatol Res 2001;293:380-381.

19 Tumwine LK, Orem J, Kerchan P, Byarugaba W, Pileri SA: EBV, HHV8 and HIV in B cell non-Hodgkin lymphoma in Kampala, Uganda. Infect Agent Cancer 2010;30; 5:12.

20 Johnston C, Orem J, Okuku F, Kalinaki M, Saracino M, Katongole-Mbidde E, Sande M, Ronald A, McAdam K, Huang ML, Drolette L, Selke S, Wald A, Corey L, Casper C: Impact of HIV infection and Kaposi sarcoma on human herpesvirus- 8 mucosal replication and dissemination in Uganda. PLoS One 2009;4: 4222 .
1 Serraino D, Angeletti C, Carrieri MP, Longo B, Piche M, Piselli P, Arbustini E, Burra P, Citterio F, Colombo V, Fuzibet JG, Dal Bello B, Targhetta S, Grasso M, Pozzetto U, Bellelli S, Dorrucci M, Dal Maso L, Busnach G, Pradier C, Rezza G: Kaposi's sarcoma in transplant and HIV-infected patients: an epidemiologic study in Italy and France. Transplantation 2005;27; 80:1699-704.

22 Shroff HJ, Dashatwar DR, Deshpande RP, Waigmann HR: AIDS-associated Kaposi's sarcoma in an Indian female. J Assoc Physicians India 1993;41:241-242.

23 Kumarasamy N, Solomon S, Madhivanan P, Ravikumar B, Thyagarajan SP, Yesudian P: Dermatologic manifestations among human immunodeficiency virus patients in south India. Int J Dermatol 2000;39:192-195.

24 Ajithkumar K, George S, Jacob M, Pulimood S, Chandi SM, Thomas PP, Jacob CK: Transplant associated Kaposis sarcoma. Indian J Cancer 1998;35:171-172.

25 Singh PN, Ranjana K, Singh YI, Singh KP, Sharma SS, Kulachandra M, Nabakumar Y, Chakrabarti A, Padhye AA, Kaufman L, Ajello L: Indigenous disseminated Penicillium marneffei infection in the state of Manipur, India: report of four autochthonous cases. J Clin Microbiol 1999;37:2699-2702. 